\title{
PhysicalActivity Resource and User Characteristics in Puerto Vallarta, Mexico Recursos para la actividad física y características de los usuarios en Puerto Vallarta, México
}

\author{
*Erica G. Soltero, ${ }^{* *}$ Scherezade K. Mama, ${ }^{*}$ Ann M. Pacheco, $* * *$ Rebecca E. Lee
}

*University of Houston, **The University of Texas MD Anderson Cancer Center, ***College of Nursing and Health Innovation,

Arizona State University

\begin{abstract}
Physical activity resources (PARs) are valuable settings for physical activity (PA) in Latin countries. PAR quality, amenities, and features are strongly associated with PA. However, the relationship between PAR characteristics and PAR usege has not been investigated in Mexico. This study aimed to describe and evaluate PARs and their association with PAR users and determine whether user and PAR characteristics differed by resource type, proximity to the ocean, or neighborhood socioeconomic status (SES) status in Puerto Vallarta, Mexico. Assessed PARs $(N=8)$ included parks $(N=5)$, a freestanding plaza $(N=1)$, and plazas combined with a park $(N=2)$.The Physical Activity Resource Assessment (PARA (O2010) was used to evaluate PAR amenities, features, and incivilities. The PARA was adapted to include plazas and open green spaces to reflect cultural and land use differences in Mexico. The System for Observing Play and Recreation in Communities (SOPARC) was used to code the age, gender, and ethnicity of each user. Descriptive analyses were used to describe PARs and users. Correlations among PAR characteristics and users were investigated. T-tests and one-way ANOVAs were used to determine whether PAR and user characteristics differed by PAR type. All PARs were accessible, free for use, about the size of a city block, and were on average, 1.9 kilometers from the water $(S D=1.3$, Range=.1-3.2). PARs had an average of 4.4 amenities $(S D=1.6)$, 2.5 features $(S D=1.4)$, and 3.5 incivilities ( $S D=2.1$ ). The quality of amenities (Range $=0-39, M=11.0, S D=4.8$ ) and features (Range $=0-36, M=6.4, S D=3.6$ ) was low, and severity of incivilities was high (Range $=0-36, M=29.9, S D=4.1)$. Eighty-one users (60.5\% men) were observed, with plazas attracting more users $(m=38.0)$ than parks $(m=6.8)$ or combination resources $(m=4.5)$. PAR users were mostly adults $(59.2 \%)$, with some children $(28.4 \%)$ and few adolescents $(12.4 \%)$. The quality of amenities was correlated with the total number of users $(r=.74, p=.04)$. There were no differences in count or quality of amenities, features, or incivilities $(p \mathrm{~s}>05)$ by resource type. The plaza attracted more women compared to parks and combination resources $(F=15.84, d f=2.5$, $p=.01)$. More adolescents $(F=7.29, d f=2.5, p=.03)$ and adults $(F=14.64, d f=2.5, p=.01)$ were observed at the plaza compared to the parks or combination resources. PARs were highly accessible, yet the presence and quality of amenities and features was poor and incivilities were high. Parks were most common; however, the plaza attracted the most users, including women, teens, and adults. Findings indicate that increasing the quality of amenities may be an effective strategy for promoting PA. Poor quality of amenities and features may have limited the ability to detect associations with users.
\end{abstract}

Keywords: Physical Activity, Park Use, Latin America, Built Environment, Features, Incivilities, Amenities.

Resumen. Antecedentes: Los recursos de actividad física (RsAF) son ámbitos de valor para la actividad física (AF) en los países latinos. La calidad, comodidades y características de los RAF están fuertemente asociadas con la AF. Sin embargo, la relación entre las características y el uso de los RAF no se han investigado en México. Objetivo: Este estudio tuvo como objetivo describir y evaluar los RAF y su asociación con los usuarios de los RAF, y determinar si los usuarios y las características de los RAF difieren por tipo de recurso, la proximidad al mar, o el nivel socioeconómico del vecindario, en el estado de Puerto Vallarta, México. Métodos: Los RsAF fueron evaluados $(\mathrm{N}=8)$ incluyendo parques $(\mathrm{N}=5)$, una plaza independiente $(\mathrm{N}=1)$, y plazas combinadas con un parque ( $\mathrm{N}=2$ ). La Evaluación de los Recursos de Actividad física (PARA @ 2010) fue usada para evaluar las comodidades, las características y los actos incívicos de los RAF. El PARA fue adaptado para incluir plazas y espacios verdes para reflejar las diferencias culturales y el uso de la tierra en México. El Sistema de Observación de Juego y Recreación en Comunidades (SOPARC) se utilizó para codificar la edad, el género y la etnia de cada usuario. Los análisis descriptivos fueron usados para describir los RsAF y los usuarios. Se investigaron las correlaciones entre los usuarios y las características de los RAF. Se utilizaron Pruebas T y un ANOVAs unidireccional para determinar si las características del usuario y las características de los RAF diferían según el tipo de RAF. Resultados: Todos los RAF eran accesibles, gratis para su uso, aproximadamente del tamaño de una manzana de la ciudad, y estaban, de promedio, a 1,9 km del agua $(\mathrm{SD}=1.3$, rango $=.1-3.2)$. Los RAF tenían una media de 4.4 instalaciones $(\mathrm{SD}=1.6)$, 2.5 características $(\mathrm{SD}=1.4)$ y 3.5 actos incívicos $(\mathrm{DE}=2.1$ ). La calidad de las instalaciones (Rango $=0-39, \mathrm{M}=11.0, \mathrm{SD}=4.8$ ) y características (rango $=0-36, \mathrm{M}=6.4, \mathrm{SD}=3.6$ ) fueron bajas, y la gravedad de los actos incívicos fue alta (gama $=0-36, \mathrm{M}=29,9, \mathrm{SD}=4.1$ ). Ochenta y un usuarios ( $60.5 \%$ varones) fueron observados, las plazas atraen a más usuarios $(\mathrm{m}=38.0)$ que los parques $(\mathrm{m}=6.8)$ o recursos combinados $(\mathrm{m}=4.5)$. Los usuarios de los RAF eran en su mayoría adultos (59.2\%) con algunos niños (28.4\%) y pocos adolescentes (12.4\%). El número total de usuarios se correlacionó con la calidad de las instalaciones $(r=0,74, p=0,04)$. No hubo diferencias en el recuento o la calidad de las instalaciones, características o actos incívicos (p> .05) por tipo de recurso. La plaza atrajo a más mujeres en comparación con los parques y los recursos combinados $(\mathrm{F}=15,84, \mathrm{df}=2,5 ; \mathrm{p}=0,01)$. Más adolescentes $(\mathrm{F}=7.29, \mathrm{df}=2.5 ; \mathrm{p}=3$. $)$ y adultos $(\mathrm{F}=14.64, \mathrm{df}=2.5 ; \mathrm{p}=.01)$ se observaron en la plaza frente a los parques o recursos combinados. Conclusiones: Los RAF eran muy accesibles, sin embargo, la presencia y calidad de instalaciones y servicios fue deficiente y los actos incívicos eran altos. Los parques fueron más comunes; sin embargo, la plaza atrajo la mayor cantidad de usuarios, incluidas las mujeres, adolescentes y adultos. Los resultados indican que el aumento de la calidad de las instalaciones puede ser una estrategia eficaz para promover la AF. La mala calidad de las instalaciones y servicios puede haber limitado la capacidad de detectar asociaciones con los usuarios.

Palabras clave. Actividad física, uso parques, América Latina, entorno construido, funciones, actos incívicos, servicios.

\section{Introduction}

Physical inactivity has become a global public health concern, as significant declines in physical activity (PA) have been observed in developed and developing countries (Heroux et al., 2013). In Mexico, the majority of children and adults fail to meet PA recommendations, and recent observations have shown that PA levels among children continue to decline with age in this population (Jauregui et al., 2011; Morales-Ruan Mdel, Hernandez-Prado, Gomez-Acosta, Shamah-Levy, \& Cuevas-Nasu, 2009; Perez-Rodriguez, Melendez, Nieto, Aranda, \& Pfeffer, 2012). High levels of physical inactivity have contributed to

Fecha recepción: 30-09-14- Fecha envío revisores: 30-09-14- Fecha de aceptación: 15-11-14 Erica G. Soltero

Erica.Soltero@uh.edu alarming rates of childhood obesity and increased prevalence of noncommunicable diseases, such as cardiovascular disease and Type 2 diabetes, the two main causes of mortality in Mexico (Galaviz et al., 2013; Lee, Shiroma et al., 2012; Romero-Martinez et al., 2013; Rtveladze et al., 2014).

Physical activity resources (PARs) such as parks and open spaces are valuable settings for PApromotion and have been widely incorporated into PApromotion strategies and programs in Latin American countries, like Mexico (Lee, Booth, Reese-Smith, Regan, \& Howard, 2005; Parra et al., 2010). The presence of PARs has been directly and indirectly linked to increased PA in children, adolescents and adults, as PARs increase opportunities for social interaction, are conveniently located within the community, are highly accessible with low to no cost, and offer a diverse range of environments for engaging in PA(Epstein et al., 2006; Lee, Cubbin, \& Winkleby, 2007; Lee, Mama, Adamus-Leach, \& 
Soltero, 2014; Lee, Mama, Banda, Bryant, \& McAlexander, 2009; Lopez, 2011; Potwarka, Kaczynski, \& Flack, 2008; Staten et al., 2012; Veitch etal., 2014). While access and availability of PARs has a significant impact on PA, research in high-income countries has shown that the use of PARs is also dependent on the quality of the PAR, which includes the presence and condition of amenities, features, and incivilities (Lee et al., 2005; Lee et al., 2014; Perry, Saelens, \& Thompson, 2011).Amenities, like benches, lighting, and sidewalks, add aesthetic appeal, and features, such as basketball courts, soccer fields, and playgrounds, encourage structured and unstructured PA (Hoehner, Brennan Ramirez, Elliott, Handy, \& Brownson, 2005; Kaczynski, Potwarka, \& Saelens, 2008; Sugiyama, Francis, Middleton, Owen, \& Giles-Corti, 2010; Tappe, Glanz, Sallis, Zhou, \& Saelens, 2013). The presence of incivilities, such as litter, graffiti, and vandalism, may create negative perceptions and safety concerns, discouraging PA (Cohen et al., 2014; McAlexander, Mama, Medina, O’Connor, \& Lee, 2011). These findings have demonstrated that the mere presence of PARs may not be enough and that researchers must also consider the influence of quality and other contextual environmental factors on PA (Lee, Adamus-Leach et al., 2012; Lee \& Cubbin, 2009).

Research in high-income countries has also shown that there are disparities in the availability and quality of PARs across neighborhood socioeconomic status (SES) levels (Lee \& Cubbin, 2009). PARs in low SES neighborhoods tend to be poorer in quality with fewer amenities and features and increased presence of incivilities compared to PARs in high SES neighborhoods (Estabrooks, Lee, \& Gyurcsik, 2003; Lee et al., 2005; Lee et al., 2007). These disparities can discourage the use of PARs among residents of low SES neighborhoods leading to decreased levels of PA (Lee et al., 2007; Lee et al., 2014).

Examining the relationship between PAR characteristics and PAR use can increase our understanding of environmental contexts that can support healthy PA habits in children and adults (Lee et al., 2005; Lee et al., 2014; McAlexander et al., 2011; Vaughan et al., 2013). However, the relationship between PAR characteristics and PAR use has not been explored in Mexico or any LatinAmerican country, to date. The aims of this study were to describe and evaluate PAR characteristics and their association with PAR users and to determine whether user and PAR characteristics differed by resource type, proximity to a body of water, or neighborhood SES status in Puerto Vallarta, Mexico. Due to the high prevalence of obesity and related non-communicable diseases, there is a growing need to address rising rates of physical inactivity in the Mexican population. Understanding environmental factors that influence the use of PARs among children and adults in Mexico will inform future PA promotion strategies and will provide direction for community and government planning and design teams (Perry et al., 2011).

\section{Methods}

This study was part of the Understanding Health Habits in Mexican Children project, a multi-site, cross-sectional study conducted in Guadalajara, Puerto Vallarta, and Mexico City, Mexico. The purpose of this project was to define, determine, and document relationships between neighborhood environmental factors and physical activity in a school-based sample of children. This study includes environmental data collected in school neighborhoods $(N=7)$ in Puerto Vallarta. Neighborhoods were defined as an 800 meter radius circumscribed around a public elementary school in each neighborhood (Lee et al., 2005). School neighborhoods were selected for participation in the study by the State of Jalisco Secretary of Education. Neighborhoods were identified in advance using Google Mexico searches and Google Earth to verify their location. Trained field assessors verified the location of school neighborhoods using pre-printed neighborhood maps and collected data on 8 pre-identified PARs while in the field. Assessed PARs were mapped using Google Earth which allowed calculation of the proximity of the PAR to the ocean. PARs were classified as closer in proximity if they were within 2.1 kilometers from the ocean and farther in proximity if they were greater than 2.1 kilometers.

\section{PAR Characteristics}

The Physical Activity Resource Assessment (PARA @2010) instrument was used to measure all identified PARs in eachneighborhood (Lee et al., 2005). The PARA classifies PARs into eight different resource types including fitness clubs, parks, sport facilities, trails, community centers, churches, schools, and combination resources. Minor adaptations were made to the PARA to add plazas and open green or beach spaces to the list of resource types based on previous formative research in Mexico that suggested cultural differences in PARs. In addition to providing information on the type of resource, the PARA provides a count and quality evaluation of PAR amenities, features, and incivilities (Lee et al., 2014). The PARA has shown good reliability (Lee et al., 2005) and was translated and back translated to Spanish by a team of LatinAmerican native bilingual speakers.

\section{PARUsers}

PAR users were observed using the System for Observing Play and Recreation in Communities (SOPARC). The SOPARC is a systematic direct observation tool that provides information on the level of intensity (walking or vigorous) and type of PA, sex, race/ ethnicity, and age group of observed PAR users (McKenzie, Cohen, Sehgal, Williamson, \& Golinelli, 2006). SOPARC is a valid tool and is reliable for use during daylight hours (Buehler, 2012). Trained assessors were grouped in pairs and assigned to a school neighborhood to assess a pre-identified PAR. Assessors identified a target area to assess at each resource. Target areas are defined as observation areas in which park users engage in physical activity. At each PAR, assessors recorded a primary and secondary activity for women and a primary and secondary activity for men. One assessor conducted a left to right observation sweep of the target area, calling out the characteristics of all observed PAR users inside the target area. The second assessor recorded the called out age (adult, teen or child), gender (male or female), and ethnicity for each individual inside the target area (McKenzie et al., 2006). Separate observations were conducted for women and men. PAR users were assessed using SOPARC during two 1 hour morning and evening observations on one weekend day. These observation time periods were adapted from the original protocol to capture as many PAR users as possible and be feasible within the scope of resources available to conduct the study.

\section{Neighborhood SES}

Neighborhood level poverty index and education was measured using the 2010 Urban Poverty Index from the National Council of Population. This poverty index is a composite measure of education, income, household, and population density measured at the census tract level. The index classifies census tracts into five categories from 'very high' to 'very low'. Education level is measured in quartiles, and census tracts are categorized into four categories from 'low' to 'high.'

\section{Protocol}

Field assessors were trained by the PI or research coordinators to complete a modified version of the PARA and SOPARC. Assessors completed in-class trainings before completing a field training to become acclimated to the built environment in Mexico. Assessors were grouped in pairs and assigned to neighborhoods to conduct assessments. Standard safety protocols were followed while assessors conducted environmental assessments (Lee et al., 2005). Upon completion, all PARA and SOPARC forms were checked for accuracy and completion before assessors returned from the field.

\section{Data Analysis}

Descriptive analyses were used to describe PARs and PAR users. Pearson's bivariate correlations were used to investigate associations among PAR and user characteristics. T-tests and one-way ANOVAs were used to determine whether user characteristics and PAR characteristics differed by PAR resource type, proximity of the PAR to the ocean, or by neighborhood level poverty index or education level. 


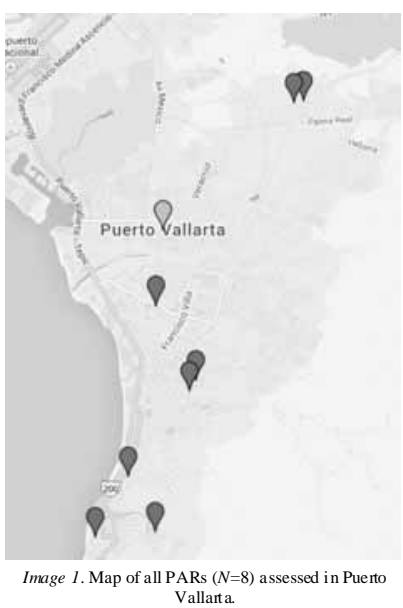

Results

PARs that were assessed $(N=8)$ included parks $(N=5)$, a freestanding plaza $(N=1)$, and plazas combined with a park $(N=2)$. All PARs were accessible, free for use, about the size of a city block, and were on average, 1.9 kilometers from the water $(S D=1.2$, Range=.1-3.2; See Image 1). PARs had an average of 4.4 amenities $(S D=1.6), 2.5$ features $(S D=1.4)$, and 3.5 incivilities $(S D=2.1$; Figure 1$)$.

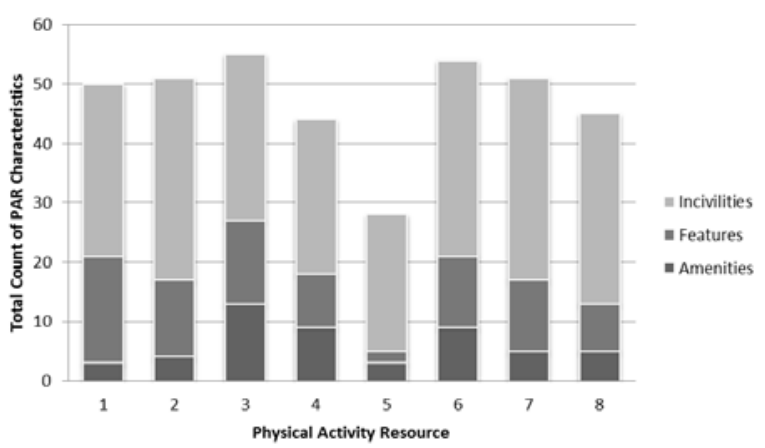
Figure 1. Total counts of amenities, features and incivilities for each PAR. Resource 1 is a plaza, resources

The quality of amenities (Range $=0-39, M=11.0, S D=4.8$ ) and features (Range=0-36, $M=6.4, S D=3.6$ ) was low, and the severity of incivilities was high (Range=0-36, $M=29.9, S D=4.1$ ). Eighty-one users (60.5\% men) were observed, with plazas attracting more users $(m=38)$ compared to parks ( $m=6.8$ ) or combination resources $(m=4.5)$. PAR users were Hispanic (96.3\%), and mostly adults (59.2\%), with some children (28.4\%) and fewer adolescents (12.4\%; Figure 2).

The total number of adult PAR users was correlated with the number of amenities ( $r=.73, p=.04$ ); however, no other age group was correlated with PAR characteristics. The total number of park users was positively correlated with the quality of amenities ( $r=.74, p=.04)$, but not features $(r=.04, p=.93)$ or incivilities ( $r=-.02, p=.97)$. Among the three resource types, there was no significant difference in count or quality of amenities, features, or incivilities. The plaza attracted more women $(m=17)$ compared to parks $(m=5)$ and combination resources $(m=3 ; F(2,5)=15.84, p=.01)$, and more teens $(F(2,5)=7.29, p=.03)$ and adults $(F(2,5)=14.64, p=.01)$ were observed at the plaza compared to parks or combination resources.

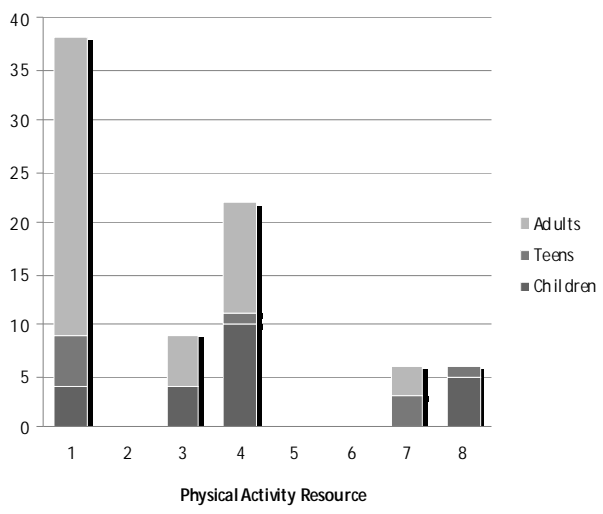

Figure 20

Figure $2 b$
Neither PAR users nor PAR characteristics differed by proximity of the PAR to the ocean or based on the poverty index of residents within the neighborhood buffer ( $p s>$.05). PAR user characteristics did not differ based on the neighborhood education level ( $p s>.05)$, but the total features score was significantly higher for neighborhoods with higher education levels $(F(2,5)=16.22, p=.01)$.

\section{Discussion}

PARs in Puerto Vallarta were widely available in all neighborhoods and were highly accessible to all neighborhood residents. However, the quality of PARs was poor, with low levels of amenities and features and high levels of incivilities. Across all PARs, there were more men than women using resources. This is consistent with other findings that have reported that most park users are male (Cohen et al., 2014). Of the three resource types, plazas attracted the most users, including more women and teens. Plazas are a defining feature in Mexican urban architecture and culture. Historically, plazas have served as places where friends meet, news is shared, goods can be purchased, and civic activities take place (Nunez, Abonce, Arvizu, \& Quantrill, 2007; Wagner, Box, \& Morehead, 2013). The social and communal nature of plazas within the Mexican community may play a role in attracting women and teens, two groups that are disproportionately inactive (Lee \& Cubbin, 2009; Nunez et al., 2007; Wagner et al., 2013).

The total number of park users was positively correlated with the quality of amenities. This is consistent with findings from high-income settings that have found that increased quality of amenities is associated with increased use, highlighting the importance of designing and maintaining PAR amenities (Hoehner et al., 2005; Kaczynski et al., 2008; Lee et al., 2005; Sugiyama et al., 2010). Increasing the presence of amenities that add to the overall aesthetic appeal of the resource, such as benches, lighting, and sidewalks, can promote increased use of the PAR which can ultimately improve PA levels (Lee et al., 2005). There was no relationship between age of users and PAR characteristics. Because there were so few amenities and features in the PARs that were observed, there may have not been enough variance in scores to detect a relationship between these PAR characteristics and PAR users. These findings further highlight theneed to design PARs with adequate amenities and features while maintaining amenities and features in existing PARs (Adamus-Leach, Mama, O’Connor, \& Lee, 2012; Lee et al., 2014; Veitch et al., 2014). Improving these PAR characteristics is particularly important for promoting PAamong youth as PAR use in teens has been associated with increased features, such as fields and courts, and increased PAR use in children has been directly linked to the increased availability of interactive play equipment (Perry et al., 2011; Veitch, Bagley, Ball, \& Salmon, 2006).

User and PAR characteristics did not differ based on the PARs proximity to the ocean, and there were no differences in PAR users or characteristics across poverty index levels. However, the total feature score was significantly higher for neighborhoods with higher education levels. Similar research in other Mexican cities and Latin American

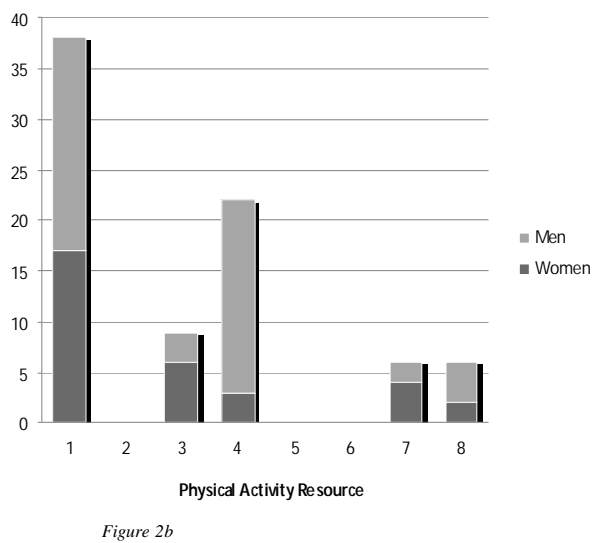


countries is needed in order to further examine the relationships among neighborhood SES, PAR users, and PAR characteristics.

As culture can influence PAR use, it is important to study PAR characteristics and use in specific populations and cultural contexts. Plazas are culturally important to the landscape of Mexico and have been used to promote PA through activities, such as dance classes or walking for exercise. Future research should further investigate the relationships among plazas, women and teens in order to explore plazas as potential resources for promoting PA in these groups. Research is also needed in other Mexican cities to validate these findings and further understand the relationship between PAR characteristics and PAR use in Mexico. Identifying PAR characteristics that create attractive and supportive environments for users can help guide PA promotion strategies. As PARs were widely available and free for use in almost all neighborhoods, public health programs can capitalize on these resources in an effort to bring PApromotion efforts into the community (Jauregui etal., 2015; Zieff, Hipp, Eyler, \& Kim, 2013).Anincreased understanding of the relationship between PAR characteristics and PAR usage will also reveal areas for policy and intervention efforts (Lee et al., 2007). This information will also provide important insight that can guide health officials, city planners and park administrators, helping to optimize the design and maintenance of PARs to encourage and sustain PAacross all age groups (Lee et al., 2007; Veitch et al., 2014).

\section{References}

Adamus-Leach, H. J., Mama, S. K., O’Connor, D. P., \& Lee, R. E. (2012). Income differences in perceivedneighborhoodenvironment characteristics among african american women. Environ Health Insights, 6, 33-40. doi: 10.4137/ EHI.S10655ehi-6-2012-033

Buehler, J. W. (2012). CDC's vision for public health surveillance in the 21st century. Introduction. MMWR Surveill Summ, 2012(27), 1-2.

Cohen, D. A., Han, B., Isacoff, J., Shulaker, B., Williamson, S., Marsh, T. (2014). Impact of Park Renovations on Park Use and Park-Based Physical Activity. $J$ Phys Act Health, 2014, 20.

Epstein, L. H., Raja, S., Gold, S. S., Paluch, R. A., Pak, Y., \& Roemmich, J. N. (2006). Reducing sedentary behavior: the relationship between park area and the physical activity of youth. Psychol Sci, 17(8), 654-659.

Estabrooks, P. A., Lee, R. E., \& Gyurcsik, N. C. (2003). Resources for physical activity participation: does availability and accessibility differ by neighborhood socioeconomic status? Ann Behav Med, 25(2), 100-104.

Galaviz, K. I., Harden, S. M., Smith, E., Blackman, K. C., Berrey, L. M., Mama S. K. (2013). Physical activity promotion in Latin American populations: a systematic review on issues of internal and external validity. Int J Behav Nutr Phys Act, 11(77), 1479-5868.

Heroux, M., Onywera, V., Tremblay, M. S., Adamo, K. B., Lopez Taylor, J., Jauregui Ulloa, E. (2013). The Relation between Aerobic Fitness, Muscula Fitness, and Obesity in Children from Three Countries at Different Stages of the Physical Activity Transition. ISRN Obes, 2013(134835), 2013.

Hoehner, C. M., Brennan Ramirez, L. K., Elliott, M. B., Handy, S. L., \& Brownson, R. C. (2005). Perceived and objective environmental measures and physical activity among urban adults. Am J Prev Med, 28(2 Suppl 2), 105-116

Jauregui, E., Pacheco, A., Soltero, E. G., O’Connor, T. M., Castro, C. M., Estabrooks, P.A. (2015). Using the RE-AIM Framework to Evaluate Physical Activity Public Health Programs in México.

Jauregui, A., Villalpando, S., Rangel-Baltazar, E., Castro-Hernandez, J., LaraZamudio, Y., \& Mendez-Gomez-Humaran, I. (2011). The physical activity level of Mexican children decreases upon entry to elementary school. Salud Publica Mex, 53(3), 228-236.

Kaczynski, A. T., Potwarka, L. R., \& Saelens, B. E. (2008). Association of park size, distance, and features with physical activity in neighborhood parks. Am J Public Health, 98(8), 1451-1456. doi: AJPH.2007.129064 [pii] 10.2105/ AJPH.2007.129064

Lee, R. E., Adamus-Leach, H., Cheung, K., Soltero, E., Lopez 3rd, Y., Saavedra, F. (2012). Researching Those Who Have the Most to Gain: Focused Physical Activity Promotion in Lower Socioeconomic Populations. Current Cardiovascular Risk Reports, 6(4), 355-361. doi: 10.1007/s12170-012-02433

Lee, R. E., Booth, K., Reese-Smith, J., Regan, G., \& Howard, H. (2005). The Physical Activity Resource Assessment(PARA) instrument: evaluating features, amenities and incivilities of physical activity resources in urban neighborhoods. Int J Behav Nutr Phys Act, 2, 13.
Lee, R. E., Cubbin, C. (2009). Striding toward social justice: the ecologic milieu of physical activity. Exerc Sport Sci Rev, 37(1), 10-17.

Lee, R. E., Cubbin, C., \& Winkleby, M. (2007). Contribution of neighbourhood socioeconomic status and physical activity resources to physical activity among women. JEpidemiol Community Health, 61(10), 882-890.

Lee, R. E., Mama, S. K., Banda, J.A., Bryant, L. G., \& McAlexander, K. P. (2009). Physical activity opportunities in low socioeconomic status neighbourhoods. J Epidemiol Community Health, 63(12), 091173.

Lee, I. M., Shiroma, E. J., Lobelo, F., Puska, P., Blair, S. N., \& Katzmarzyk, P. T. (2012). Effect of physical inactivity on major non-communicable diseases worldwide: an analysis of burden of diseaseand lifeexpectancy.Lancet,380(9838), 219-229.

Lopez, R. (2011). The Potential of Safe, Secure and Accessible Playgrounds to Increase Children's Physicial Activity Active Living Research.

McAlexander, K. M., Mama, S. K., Medina, A., O’Connor, D. P., \& Lee, R. E. (2011). The concordance of directly and indirectly measured built environment attributes and physical activity adoption. Int J Behav Nutr Phys Act, 8(72), 1479-5868.

McKenzie, T. L., Cohen, D. A., Sehgal, A., Williamson, S., \& Golinelli, D. (2006). System for Observing Play and Recreation in Communities(SOPARC): Reliability and Feasibility Measures. J Phys Act Health, 3 Suppl 1, S208S222.

Morales-Ruan Mdel, C., Hernandez-Prado, B., Gomez-Acosta, L. M., ShamahLevy, T., \& Cuevas-Nasu, L. (2009). Obesity, overweight, screen time and physical activity in Mexican adolescents. Salud Publica Mex, 51(4), S613-620.

Nunez, F., Abonce, R., Arvizu, C., \& Quantrill, M. (2007). Space and place in the Mexican landscape: the evolution of a colonial city. College Station: TexasA \& M University Press.

Parra, D. C., McKenzie, T. L., Ribeiro, I. C., Ferreira Hino, A. A., Dreisinger, M., Coniglio, K. (2010). Assessing physical activity in public parks in Brazil using systematic observation. Am J Public Health, 100(8), 1420-1426.

Perez-Rodriguez, M., Melendez, G, Nieto, C., Aranda, M., \& Pfeffer, F. (2012). Dietary and physical activity/inactivity factors associated with obesity in schoolaged children. Adv Nutr, 3(4), 001974.

Perry, C. K., Saelens, B. E., \& Thompson, B. (2011). Rural Latino youth park use: characteristics, park amenities, and physical activity. J Community Health, 36(3), 389-397.

Potwarka, L. R., Kaczynski,A. T., \& Flack,A. L. (2008). Places to play: association of park space and facilities with healthy weight status among children. $J$ Community Health, 33(5), 344-350.

Romero-Martinez, M., Shamah-Levy, T., Franco-Nunez,A., Villalpando, S., CuevasNasu, L., Gutierrez, J. P. (2013). [National Health and Nutrition Survey 2012: design and coverage]. Salud Publica Mex, 55 Suppl 2, S332-340. doi: S003636342013000800033 [pii]

Rtveladze, K., Marsh, T., Barquera, S., Sanchez Romero, L. M., Levy, D., Melendez, G. (2014). Obesity prevalence in Mexico: impact on health and economic burden. Public Health Nutr, 17(1), 233-239.

Staten, L. K., Cutshaw, C.A., Davidson, C., Reinschmidt, K., Stewart, R., \& Roe, D. J.(2012). Effectiveness of the PasosAdelante chronic disease prevention and control program in a US-Mexico border community, 2005-2008. Prev Chronic Dis, 2012(9), 15

Sugiyama, T., Francis, J., Middleton, N. J., Owen, N., \& Giles-Corti, B. (2010). Associations between recreational walking and attractiveness, size, and proximity of neighborhood open spaces. Am J Public Health, 100(9), 1752-1757.

Tappe, K.A., Glanz, K., Sallis, J. F., Zhou, C., \& Saelens, B. E. (2013). Children’s physical activity and parents' perception of the neighborhood environment: neighborhood impact on kids study. Int J Behav Nutr Phys Act, 10(39), 14795868.

Vaughan, K. B., Kaczynski, A. T., Wilhelm Stanis, S. A., Besenyi, G. M., Bergstrom, R., \& Heinrich, K. M. (2013). Exploring the distribution of park availability, features, and quality across Kansas City, Missouri by income and race/ethnicity: an environmental justice investigation. Ann Behav Med, 45 Suppl 1, S28-38. doi: 10.1007/s12160-012-9425-y

Veitch, J., Bagley, S., Ball, K., \& Salmon, J. (2006). Where do children usually play? A qualitative study of parents' perceptions of influences on children's active free-play. Health Place, 12(4), 383-393.

Veitch, J., Salmon, J., Carver, A., Timperio, A., Crawford, D., Fletcher, E. (2014). A natural experiment to examine the impact of park renewal on park-use and park-based physical activity in a disadvantaged neighbourhood: the REVAMP study methods. BMC Public Health, 14(600), 1471-2458.

Wagner, L., Box, H., \& Morehead, S. K. (2013). Ancient origins of the Mexican plaza: from primordial sea to public space. Austin: University of Texas Press.

Zieff, S. G, Hipp, J. A., Eyler, A. A., \& Kim, M. S. (2013). Ciclovia initiatives: engaging communities, partners, and policy makers along the route to success. J Public Health Manag Pract, 19(3 Suppl 1). 